\title{
MARKET INTEGRATION AS A DETERMINANT OF AGRICULTURAL PRICES AND ECONOMIC RESULTS OF SMALL-SCALE FAMILY FARMS
}

\author{
Sebastian Stepien ${ }^{1}$, PhD; Jan Polcyn ${ }^{2}, \mathrm{PhD}$ \\ ${ }^{1}$ Poznan University of Economics and Business, ${ }^{2}$ Stanislaw Staszic State University of Applied \\ Sciences in Pila
}

\begin{abstract}
Due to the specific features of the land factor, under market conditions, there is a tendency towards income deprivation of farms in relation to their surroundings. One way to improve this situation is to create a system of market institutions for farmer-recipient transactions. The issue of the position of the agricultural producer in the food supply chain is widely described in the literature on the subject. Nevertheless, practical analyses showing the real impact of the marketing position on economic results of farm are still rare. Therefore, the aim of this article is to assess the relationship between market integration and agricultural selling prices and, as a consequence, the level of global output and household income. The analysis is based on primary data from surveys of over 700 small-scale family farms in Poland. The choice of small-scale farms was deliberate, as these entities are the most discriminated against in the food supply chain. Explaining this process is key to improving the economic situation of small-scale farming and constitutes a premise for the objectives of agricultural policy and creating business strategy. The results of the research indicate that there is a positive correlation between the level of integration of an agricultural holding and sales prices for selected groups of agricultural products. This, in turn, leads to the improvement of economic condition of farms more closely integrated with the market.
\end{abstract}

Key words: small-scale family farms, market integration, agricultural prices, economic results, Poland.

JEL code: Q12, Q13, D23

\section{Introduction}

In the practice of agricultural activity, one can encounter the phenomenon of deprivation of small-scale family farms in relation to the closer and further economic surroundings. The problem lies in the ability to accumulate and conduct extended production, i.e. to produce food, while achieving income at a level that allows at least the replacement of fixed assets involved in the production and ensuring a fair payment of the farmer's labour (Poczta-Wajda A., 2016). A symptom of relative deprivation is the difference between incomes in the agricultural sector and other sectors of the economy, to the detriment of the first group. As indicated by Guth et al. (2020) agricultural gap ratio ${ }^{3}$ for EU countries in the years 2005-2015 accounted, on average, for $34 \%$ including the payments under Common Agricultural Policy, and $131 \%$ without payments. The scale of the disproportion is particularly strong in the new Member States as the ratio without subsidies in these countries is almost $50 \%$ higher than in the EU-15 states. The deprivation of farms is based on specific conditions of the land factor, such as low price elasticity and income elasticity of demand for agricultural products, a large share of the random component shaping the volume of production (dependence on natural and climatic factors), limited mobility of invested assets, long period of capital return, higher than in other sectors the seasonality and cyclicality of supply and prices. These determinants influence the lack of income stability and difficulties in management at a high level of risk (Czyzewski A., Stepień S., 2017). Under these conditions, the economic surplus generated by agricultural producers, which is a condition for capital development (see: Piketty, 2013), does not meet the Pareto optimal allocation criterion in input-output flows. In the supply chain, it is captured partly by middlemen and processors and ultimately consumers. The implementation of broadly understood institutions of the agribusiness corrects these failures of the market mechanism. Only then will the economic rent encourage farms to provide services in the long term (Czyzewski B., Matuszczak A., 2016).

1 Poznan University of Economics and Business, Al. Niepodległosci 10,61-875 Poznan, Poland, tel. +48 696411391 , e-mail: sebastian.stepien@ue.poznan.pl 2 Stanislaw Staszic State University of Applied Sciences in Pila, ul. Podchorazych 10, 64-920 Pila, Poland, tel. +48 666346901 , e-

mail:Jan.Polcyn@puss.pila.pl

3 Agricultural gap ratio = (average income per capita in national economy - average farm income per family work unit)/average income per capita in national economy. 
The examples of institutions which eliminate the negative effects of the market mechanism in agriculture are coordinated systems of production and transactions of foodstuffs. In the outlined context, the coordinated production and sales systems refer to shortening the supply chain, establishing durable longterm relationships with contractors, creating integrated forms of distribution and developing vertical and horizontal integration. According to the adopted assumption, such institutions include all formal and informal rules governing human interactions (North D., 1990). They usually concern the conditions for transaction between buyers and sellers. When institutions run smoothly, they guarantee the continuity of the rules and mechanisms of transactions by reducing the uncertainty and risk of economic processes and providing greater predictability of stable prices and income (Hayami Y., Ruttan V. W., 1985). Thus, they can be seen as an expression of efforts to improve the economic well-being of farms. The creation of coordinated forms of activity is particularly important in relation to small-scale family farms. Smaller players participate in the distribution of food supply margin to an inadequate degree because of the disproportions of the bargaining power that individual entities have in the subsequent stages of the marketing chain. Small producers, which are the initial link in the supply chain, have limited opportunities to shape the terms of the transaction (Pazaj E., Dumi A., 2015). This type of situation is typical for the countries of Central and Eastern Europe. Hence, the aim of the paper is to determine the relationship between the market integration of small-scale family farms in Poland and their position in the supply chain expressed through the level of selling prices of agricultural products and, as a consequence, the size of global output and household income. The authors hypothesize that farms more closely integrated with the market achieve higher selling prices and, consequently, better economic results of their activities. The article also attempts to define selected features for farms with a different degree of integration, which to some extent revealed the premises of the market coordination process in the agricultural sector. The analysis is based on primary data from surveys of over 700 small-scale family farms in Poland. The choice of small-scale farms was intentional, as these entities are the most discriminated against in the food supply chain and they constitute the largest share of agribusiness entities. Explaining this process is a key to improve the economic situation of small-scale farming and determines a premise for the objectives of agricultural policy and creating business strategy. The study was carried out in three steps. The first was to estimate the individual 'index of market integration'. In the second step, farms were divided into three groups in terms of market integration level and an analysis of sales prices and economic results was carried out, divided into these groups. In the third stage, selected economic and demographic features of farms were indicated, taking into account the differentiation in terms of market integration.

\section{Research results and discussion}

\section{Data set}

Small-scale family farms in Poland were analysed due to the role they play in the agricultural sector. In our study, we adopted three parameters for determining the sample of tested units. The first is the physical size of the holding up to 20 ha of utilised agriculture area UAA. Farms with such an area cover $90 \%$ of all farms in Poland (Statistics Poland, 2020). The second parameter is the economic size of a farm, according to the Farm Accountancy Data Network FADN typology, up to 25 thousand. euro of standard production $\mathrm{SO}^{4}$. According to the guidelines of the European Commission, farms with an economic size of up to EUR 8000 are treated as very small (7 million in the EU), and up to EUR 25000 as small (8.5 million) (European Commission, 2011; Eurostat, 2021). The third criterion is the share of at least $75 \%$ of the 4 Standard Output (SO) is the five-year average of the production value at farm selling prices, expressed in euro per hectare of agricultural area or per animal
head. 
labour inputs of family members engaged in agricultural activities. The latter, apart from designating the family farm, is also aimed at eliminating from the survey those units which are formally classified as farms, but in practice live mainly from non-agricultural sources of income. This study is based on surveys conducted on a sample of 710 farms from 16 Polish provinces in the first three months of 2018. The data was collected in the form of direct interviews by agricultural advisors who work in the Polish FADN system. In the interview, a structured questionnaire was used, which contained four thematic question blocks: economic and social sustainability, environmental sustainability, market links, general farm features. For the correctness of the collected information, pilot studies were carried out prior to the main study. Ultimately, after the elimination of incomplete questionnaires, incorrectly filled out and containing outliers, 672 units were analysed.

\section{Index of market integration}

The index of market integration was calculated using the authors' own formula. The synthetic index was composed of the following elements: 1 ) share of the farm's market sales: the higher the share, the higher the value; 2) distribution channels for agricultural products: through an intermediary; to processing plants; to a wholesale or retail chain; in a marketplace; directly from the farm or through participation in fairs or the like: the fewer intermediaries, the higher the rating; 3) type of relation with the market when selling the agricultural products: sale without previously signed contracts; sale on the basis of short-term (financial year) contracts; sale on the basis of long-term or renewed contracts; sale within a producer group or cooperative; 4) subjective assessment of the farm's market position (bargaining power) in sales transactions: terms of the contract (price, date, place etc.) are determined by the buyer; I (the farmer) mainly determine the terms of the contract; the terms of the contract are determined together; 5) type of relation with the market when purchasing means of production: without formal contracts; from regular suppliers without previously signed contracts; from regular suppliers on preferential terms or under previously signed contracts; 6) subjective assessment of the farm's market position in purchase transactions (as for point 4). Each of the elements was scored from 0 to 1 , so the total index was scored from 0 to 6 points. Finally, the index was scaled from 0 to 1.

The average integration index for all units was 0.57 . Then the farms were divided into three groups according to the level of market integration. The first group in the range of 0-0.33 included 176 farms with an average index equal to 0.28. The second group in the range of 0.34-0.67 was the most numerous 289 entities with an average index of 0.58. In the last group, there were 207 farms with an average index of 0.86 .

Table 1

Analysed farms by the level of market integration index

\begin{tabular}{|l|c|c|c|}
\hline $\begin{array}{c}\text { Group of market } \\
\text { integration }\end{array}$ & Number of farms & $\begin{array}{c}\text { Average index of } \\
\text { market integration }\end{array}$ & $\begin{array}{c}\text { Median of the index of } \\
\text { market integration }\end{array}$ \\
\hline Group 1 & 176 & 0.28 & 0.30 \\
\hline Group 2 & 289 & 0.58 & 0.57 \\
\hline Group 3 & 207 & 0.86 & 0.84 \\
\hline Totally & 672 & 0.57 & 0.58 \\
\hline
\end{tabular}

Source: author's calculations based on the survey data $\mathrm{N}=672$ 


\section{Selling prices and economic results}

Table 2 presents average selling prices of selected agricultural products for three separate groups of farms. The products for which there was a sufficiently large representation of farms were taken into account. It was assumed that the minimum number of units for each of the products and each group should be 20. As a result, data was obtained for 10 products - 7 types of crops and three types of livestock production. The data show a positive clear relationship between the degree of market integration and selling prices for 5 products - all meat and two crops. For milk, the difference is $25 \%$ in favor of group 3, for pigs $15.1 \%$, for cattle $8.7 \%$. In the case of apples, the difference is $28.6 \%$ and rapeseed $-12.1 \%$. In turn, for cereals and potatoes, the prices for all three groups of market integration level were similar. It can be assumed that this is the result of a different degree of market coordination of different agricultural subsectors. Cereals and potatoes are traditionally delivered by farms to the collection centres ad hoc without formal contracts. In the case of rape, milk, meat production or fruit production, transactions are more often formalized, hence the possibility of obtaining additional benefits by the contract parties, including higher selling prices for farms.

Table 2

\section{Selling prices of selected agricultural products for the analysed farms divided into market integration level groups}

\begin{tabular}{|c|c|c|c|c|c|c|c|c|c|c|}
\hline \multirow{2}{*}{$\begin{array}{c}\text { Group of } \\
\text { market } \\
\text { integration }\end{array}$} & \multicolumn{10}{|c|}{ Prices* } \\
\hline & Wheat & Triticale & Barley & Rye & Rape & Potatoes & Apples & Pigs & Cattle & Milk \\
\hline Group 1 & 149 & 141 & 145 & 149 & 331 & 155 & 0.28 & 1.06 & 1.72 & 0.28 \\
\hline Group 2 & 151 & 139 & 143 & 143 & 357 & 156 & 0.31 & 1.09 & 1.74 & 0.30 \\
\hline \multirow[t]{3}{*}{ Group 3} & 150 & 141 & 144 & 147 & 371 & 153 & 0.36 & 1.22 & 1.87 & 0.35 \\
\hline & \multicolumn{10}{|c|}{ Number of farms } \\
\hline & Wheat & Triticale & Barley & Rye & Rape & Potatoes & Apples & Pigs & Cattle & Milk \\
\hline Group 1 & 50 & 54 & 33 & 36 & 20 & 44 & 21 & 58 & 46 & 28 \\
\hline Group 2 & 112 & 62 & 56 & 105 & 68 & 59 & 24 & 71 & 55 & 47 \\
\hline Group 3 & 67 & 45 & 40 & 93 & 56 & 24 & 42 & 28 & 42 & 51 \\
\hline Total & 229 & 161 & 129 & 234 & 144 & 127 & 87 & 157 & 143 & 126 \\
\hline
\end{tabular}

*wheat, triticale, barley, rye, rape and potatoes - EUR/1,000 kg, pigs and cattle - EUR/kg, milk - EUR/l.

\section{Source: author's calculations based on the survey data $\mathrm{N}=672$}

Taking into account the fact that for farms more integrated on the market, at least for some agricultural products, the selling price is higher, better economic results for this group can be expected. The reflection of prices is the production value, and its derivative is the farm income. Table 3 shows that in the case of the researched farms, both production and income increase along with the rise in the degree of market integration. The average production value per farm for group 3 is $34.4 \%$ higher than for group 1 , and for disposable income as much as $48.5 \%$. Higher incomes achieved by integrated farms mean that the share of support in income is lower than for less integrated groups, which makes the group 3 less dependent on external assistance. This may be important in crisis situations in the economy, when the scope of support decreases due to budgetary constraints. On the other hand, it should be noted that even in the third group of households, the income on the farm is only EUR 303 per month per family member, thus still approx. $15 \%$ below the average income in Poland (Statistics Poland 2020). 


\section{Economic results for the analysed farms divided} into market integration level groups

\begin{tabular}{|l|c|c|c|}
\hline $\begin{array}{c}\text { Group of market } \\
\text { integration }\end{array}$ & $\begin{array}{c}\text { Annual production } \\
\text { size (euro) }\end{array}$ & $\begin{array}{c}\text { Monthly household } \\
\text { disposable income (euro) }\end{array}$ & $\begin{array}{c}\text { Support share in } \\
\text { agricultural income }\end{array}$ \\
\hline Group 1 & 9451 & 204 & $44 \%$ \\
\hline Group 2 & 11257 & 260 & $34 \%$ \\
\hline Group 3 & 12709 & 303 & $31 \%$ \\
\hline
\end{tabular}

Source: author's calculations based on the survey data $N=672$

\section{Selected features of the research farms}

Table 4 introduces several characteristics of farms separately for groups of market integration level. The first element, the farm area, varies between 12.4-13.4 ha of agricultural land. Contrary to the value of production, there was no correlation between the area and the level of integration. Thus, farms more integrated achieve higher production from a similar agricultural land area, obtaining higher land productivity indicators. This may be the result of higher selling prices (as demonstrated in sub-part 3 ) and/or better yield rates and animal slaughter performance. As for demographic characteristics there is no difference between groups in reference to the age of the farm manager. However, in the case of education, it can be noticed that it grows along with the increase in the degree of integration. Interesting are the results of the analysis from the point of view of non-professional activity of family members of the farm. It turns out that farms more integrated with the market are more involved in lifelong learning and cultural events. The above data may suggest that higher educated and more active agricultural producers stand out for a higher propensity to participate in coordinated supply chains.

Table 4

\section{Selected features of the analysed farms divided} into market integration level groups

\begin{tabular}{|c|c|c|c|}
\hline Question & Group 1 & Group 2 & Group 3 \\
\hline Farm area, in ha of UAA & 13.0 & 13.4 & 12.4 \\
\hline Age of the farm manager & 49 & 48 & 49 \\
\hline Level of education* & 4.2 & 4.7 & 4.9 \\
\hline $\begin{array}{l}\text { Share of adult farm members in lifelong learning (courses, training, } \\
\text { etc.), in } \%\end{array}$ & 49.4 & 59.4 & 63.5 \\
\hline \multicolumn{4}{|l|}{$\begin{array}{l}\text { Share of adult farm members attending cultural events (cinema, } \\
\text { theatre, concerts, exhibitions etc.) in the last } 12 \text { months before the } \\
\text { survey, in \% }\end{array}$} \\
\hline - 5 times or more & 1.3 & 7.8 & 10.4 \\
\hline - 3-4 times & 16.9 & 16.5 & 20.3 \\
\hline - 1-2 times & 27.3 & 35.1 & 35.9 \\
\hline - not at all & 54.5 & 40.6 & 33.4 \\
\hline
\end{tabular}

*education in the range of 1-7, where 1 - no education, 7 - higher education

\section{Source: author's calculations based on the survey data $N=672$}

The last analysed feature concerns the type of agricultural production. As table 5 shows there are six types of specialisation and mixed production. What draws special attention is the differentiated, for the three groups, share of farms with mixed production. In group 1 it is almost two-thirds, while in group 3 it 
is less than $20 \%$. Therefore, market-integrated farms are more specialized in agricultural production. It is understandable that they look for special solutions for transactions of larger batches of goods. Mixed farms are less inclined to these activities due to the dispersion of production and lower sales scale of selected products. On the other hand, among group 3 there is a relatively high share of farms specialised in horticulture and permanent crops, i.e. sectors with a higher than average degree of market integration in Poland (Czyzewski A., Bieniek-Majka M., Czakowski D., 2018). The specialization in the production of granivores and milk production is also higher than in the other two groups.

Table 5

Production type of the analysed farms divided into market integration level groups

\begin{tabular}{|l|c|c|c|c|c|c|}
\hline \multirow{2}{*}{\begin{tabular}{c}
\multirow{2}{*}{$\begin{array}{c}\text { Production type } \\
\text { (specialisation*) }\end{array}$} \\
\cline { 2 - 8 }
\end{tabular}} & \multicolumn{2}{c|}{ Group 1 } & \multicolumn{2}{c|}{ Group 2 } & \multicolumn{3}{c|}{ Group 3 } \\
\hline Field crops & 25 & $14.2 \%$ & 116 & $40.1 \%$ & 63 & $30.4 \%$ \\
\hline Horticulture & 1 & $0.6 \%$ & 7 & $2.4 \%$ & 21 & $10.1 \%$ \\
\hline Permanent crops & 2 & $1.1 \%$ & 8 & $2.8 \%$ & 24 & $11.6 \%$ \\
\hline Milk & 5 & $2.8 \%$ & 16 & $5.5 \%$ & 22 & $10.6 \%$ \\
\hline Herbivores & 29 & $16.5 \%$ & 34 & $11.8 \%$ & 21 & $10.1 \%$ \\
\hline Granivores & 2 & $1.1 \%$ & 14 & $4.8 \%$ & 18 & $8.7 \%$ \\
\hline Mixed production & 112 & $63.6 \%$ & 94 & $32.5 \%$ & 38 & $18.4 \%$ \\
\hline
\end{tabular}

*specialisation means that farm receives at least $2 / 3$ of global output from a given type of production. If not, it is mixed farm

\section{Source: author's calculations based on the survey data $N=672$}

\section{Discussion}

Overall, the results of the analysis indicate a positive relationship between the degree of market integration and the economic results of small-scale family farms in Poland. This connection has been confirmed in other studies, both at the level of European countries and for other regions in the world, e.g. Pendleton L. and Howe L. (2002), European Commission (2016), Arias P. et al. (2013). A positive correlation between farms' market integration and production volume was demonstrated in Romania, Bulgaria (Jambor A., 2013) and Poland (Golebiewska B., 2012). For the African continent, these results were confirmed by, among others, Kangile et al. (2020) and Oparinde and Daramola (2014). Kedaitiene and Hockmann (2002) justify the positive relationship between the market integration and value of agricultural production in Lithuania. They argue that larger batches of foodstuffs make it easier to sell agricultural products closer to the final consumer, while farms with lower production value use the services of intermediaries. This is a result of the fact that processors and traders are looking for producers who will provide them with a large and continuous supply of agricultural raw materials. Therefore, to create permanent and formal contacts in the supply chain, a minimum volume of produce is delivered (Pedro A. et al., 2013; Gani A. and Hossain E., 2015). White J. and Gorton M. (2011), analysing the agricultural sector in Moldova, Armenia, Georgia, Russia and Ukraine, indicate that during the transformation period, various forms of contracting between farms and food industry enterprises were developed, with higher dynamics for larger, in terms of production value, entities, while small-scale farms more often used spot type transactions. Other papers prove that higher market integration is conducive to obtaining higher selling prices of agricultural raw materials. Such analyses were conducted for countries of Eastern Europe and Central Asia (Hanf J. H., 2014), United States (MacDonald J. et al, 2004) and developing countries (Catelo M. A., Costales A. C., 2008). They all confirm the conclusions drawn in our study. 
Apart from the scale of production, the level of market integration is connected with the degree of production specialization, as evidenced by Kahan D. (2013) and Djuric I. et al. (2018). The authors indicate that the lowest degree of connections with its economic surroundings was characteristic of farms with differentiated production (mixed). However, the closer market orientation leads farms to shift production from mixed farming to greater specialization. It can be assumed that the pursuit of family farms to specialize is an attempt to reduce the risk of selling agricultural products. Taking into account the fact that the food industry is interested in the supply of larger, homogeneous batches of goods, such action meets the expectations of processors and facilitates the establishment of permanent contracts.

The result of analysis for the feature 'farm area' are interesting. Theoretically, it can be assumed that the larger the area of the farm, the greater the scale of production and the stronger market integration (Key N., Sadoulet E., de Janvry A., 2000). Meanwhile, such a relationship was not confirmed in our study. Therefore, it can be concluded that in the case of family farms, it is not the area of the farm that correlates with market connection but the production volume and the level of specialisation. Moreover, due to the subjective scope of the study (small-scale family farms), the range of the 'farm area' was limited to 20 ha. It is therefore uncertain whether similar results would have been obtained if medium and large farms were taken into account.

Among the two demographic characteristics, the level of market integration rises among with the level of education. Thus, it can be concluded that obtaining vocational, general or higher education is an important factor stimulating farmers' participation in market processes. Moreover, farmers should seek knowledge on operating more effectively in the supply chain. Sales management is a process of decision-making that involves setting objectives, planning, implementing the plan and monitoring its outcome, which requires the farmer to have appropriate competences and qualifications. It is not enough for farmers to learn on the job from their day-to-day experience. Farmers should not only be good workers but also entrepreneurial and innovative (Kahan D., 2013). It is indicated that for agriculture in developed and developing countries, the level of education and human capital is strongly associated with higher levels of marketing productivity and with faster rates of adoption of new technologies (Turkalj D., Biloš A., Kelić I., 2015). Moreover, farmers' competences in management and marketing as well as personality traits, such as willingness to cooperate and active citizenship, motivate to create coordinated systems of transactions and participation in the short supply chain, which is supported by the belief about benefits for farm income (Charatsari C., Kitsios F., Lioutas E. D., 2020). In turn, the second demographic feature, the farmer's age, was similar for all groups of households. Based on the available research, it is difficult to unequivocally assess the relationship of this variable with farms' market integration. Some authors claim that older and more experienced farmers are able to make better production decisions, including those of a marketing nature (Czyżewski B., Sapa A., Kułyk P., 2021; Stanef M. R., 2012; Martey E., Al-Hassan R., Kowornu J., 2012; Hailua G., Manjureb K., Aymutc K. M., 2015). In contrast, other results indicate that young-age-headed farms are more eager to participate in the market than old-age-headed households (Kangile R. J. et al., 2020). Age may have a negative impact because young people might have a longer planning horizon and might be willing to take risks related to market transactions.

\section{Conclusions, proposals, recommendations}

1) Small-scale family farms play an important role in the sustainable development of rural areas. In addition to traditional, better-quality food, they provide a range of public goods of a social and environmental nature. However, for their viability it is necessary to provide appropriate economic conditions. One of the elements influencing the economic situation of farms is the level of their market 
integration. The results of our analysis indicate, that more market-oriented farms receive higher prices of selected agricultural products and, as a result, higher production value and household income (although in relation to the non-agricultural sector, the latter remains still lower). They are also less dependent on external aid (subsidies from the UE common agricultural policy), which may be essential in the event of an unforeseen decline in support.

2) The study also demonstrates selected features of market-integrated farms. It turns out that they are more specialized in a specific type of agricultural production, managed by higher educated managers and willing to undertake extra-professional activity. On the other hand, the area of the farm and the age of the owner did not differ significantly between groups of farms with a different degree of integration.

3) The above conclusions constitute the basis for formulating recommendations for the support policy for small-scale farms, both at the European Union level (through the instruments of the common agricultural policy) and at the national level. This support should be deliberately targeted in a way that contributes to strengthening the bargaining power of small farmers. Some solutions are already present today, such as financing the activities of agricultural producer groups and industry organizations. However, the problem is the low awareness of the benefits of cooperation and the low tendency to participate in this type of relationship, hence the key becomes the education of farm managers through participation in training, courses, training etc., all the more so as, as research shows, education could have a positive effect on the level of market integration. Such events could be organized by agricultural advisory centres, agricultural unions, representatives of academic centres, and financed under rural development programs ( $2^{\text {nd }}$ pillar of the common agricultural policy). It is a good idea to prepare the so-called 'best practices' handbook. Nothing influences the imagination of a farmer as much as indicating the measurable financial effects of market cooperation.

4) The effectiveness of households' activities is also determined by the appropriate combination of sales channels, which takes into account the so-called short supply chains, including direct and marketplace sales (Rucabado-Palomar T., Cuellar-Padilla M., 2020). The transaction processes should be supported by properly prepared technical infrastructure (including specially adapted warehouses) and agricultural product contracting systems. For the efficiency of contracting, the proposed solution is to introduce greater transparency of contracts between farmers and recipients of the raw material. It might be a good idea to create a standardized contract template with a price element that would protect both parties to the transaction. The combination of these elements can effectively support logistics processes in accordance with the 'just in time' principle (Crespi J. M., Saitone T. L., 2018; Bhattar et al., 2020).

\section{Acknowledgment (funding details)}

The paper was written as a part of the project titled 'The role of small farms in the sustainable development of agri-food sector in the countries of Central and Eastern Europe', financed by the Polish National Agency for Academic Exchange, Poland (project no. PPI/APM/2018/1/00011/DEC/1) and by the National Science Centre in Poland (grant no. 2016/21/B/HS4/00653).

\section{Bibliography}

1. Arias, P., Hallam, D., Krivonos, E., Morrison, J. (2013). Smallholder Integration in Changing Food Markets. Rome: Food and Agriculture Organization FAO.

2. Catelo, M.A., Costales, A.C. (2008). Contract Farming and Other Market Institutions as Mechanisms for Integrating Smallholder Livestock Producers in the Growth and Development of the Livestock Sector in Developing Countries. PPLPI Working Paper 45. Rome: Food and Agriculture Organization FAO. 
3. Charatsari, C., Kitsios, F., Lioutas, E.D. (2020). Short Food Supply Chains: the Link between Participation and Farmers' Competencies. Renewable Agriculture and Food Systems, vol. 35, pp. 643-652.

4. Crespi, J. M., Saitone, T. L. (2018). Are Cattle Markets the Last Frontier? Vertical Coordination in Animal-Based Procurement Markets. Annual Review of Resource Economics, vol. 10(10), pp. 207-227.

5. Czyzewski, A., Bieniek-Majka, M., Czakowski, D. (2018). Factors Shaping Supply-demand Relations on the fruit and vegetable market in the light of the behavior of groups and producer organizations. Management, vol. 22(1), pp. 265-277.

6. Czyzewski, A., Stepien, S. (2017). Nowe uwarunkowania ekonomiczne wspolnej polityki rolnej (WPR) Unii Europejskiej (New economic conditions of the common agricultural policy (CAP) of the European Union). Ekonomista (Economist), vol. 6, pp. 675-697.

7. Czyzewski, B., Matuszczak, A. (2016). A New Land Rent Theory for Sustainable Agriculture. Land Use Policy, vol. 55, pp. 222-229.

8. Czyzewski, B., Sapa, A., Kulyk, P. (2021). Human Capital and Eco-Contractual Governance in Small Farms in Poland: Simultaneous Confirmatory Factor Analysis with Ordinal Variables. Agriculture, vol. 11(46). https://doi.org/10.3390/agriculture11010046.

9. Djuric, I., Gotz, L., Svanidze, M., Glauben, T. (2018). Agricultural Market Integration in the Commonwealth of Independent States: What Are the Main Driving Forces and Challenges? In: Agricultural Value Chain (ed. G. Egilmez). London: Intech Open.

10. European Commission (2011). EU Agricultural Economic Brief: What is a Small Farm?, Brief No2. Brussels: European Commission- Directorate General for Agriculture.

11. European Commission (2016). Improving Market Outcomes. Enhancing the Position of Farmers in the Supply Chain. Report of the Agricultural Markets Task. https://ec.europa.eu/info/sites/info/files/food-farmingfisheries/farming/documents/amtf-report-improving-markets-outcomes_en.pdf. Accessed: 10.12.2020.

12. Eurostat (2021). https://ec.europa.eu/eurostat/data/database. Access: 10.02.2021.

13. Gani, A., Hossain, E. (2015). Market Participation Decision of Smallholder Farmers and their Determinants in Bangladesh. Ekonomika Poljoprivrede, vol. 62, pp. 163-179. DOI: 10.5937/ekoPolj1501163G.

14. Golebiewska, B. (2012). Diversification of Farm Connections with the Environment (Zróżnicowanie powiązań gospodarstw rolniczych z otoczeniem). https://www.farmer.pl/finanse/podatki-rachunkowosc/zroznicowaniepowiazan-gospodarstw-rolniczych-z-otoczeniem,33804.html. Accessed: 05.01.2021.

15. Guth, M., Smedzik-Ambrozy, K., Czyzewski, B., Stepien, S. (2020). The Economic Sustainability of Farms under Common Agricultural Policy in the European Union Countries. Agriculture, vol 10(34). DOI: $10.3390 /$ agriculture10020034.

16. Hayami, Y., Ruttan, V. (1985). Agricultural Development: An International Perspective. Battimore: John Hopkins University Press, p. 95.

17. Hailua, G., Manjureb, K., Aymutc, K.M. (2015). Crop Commercialization and Smallholder Farmers Livelihood in Tigray Region, Ethiopia. Journal of Development and Agricultural Economics, vol. 7(9), pp. 314-322.

18. Hanf, J.H. (2014). Processor Driven Integration of Small-scale Farmers into Value Chains in Eastern Europe and Central Asia. Rome: Food and Agriculture Organization FAO.

19. Jambor, A. (2013). Country-specific Determinants of Horizontal and Vertical Intra-industry Agri-food Trade: the Case of Bulgaria and Romania. Applied Studies in Agribusiness and Commerce, vol. 7(4-5), pp. 1-8. DOI:10.22004/ag.econ.187510.

20. Kahan, D. (2013). Market-oriented Farming: an Overview. Rome: Food and Agriculture Organization FAO.

21. Kangile, R.J., Mgeni, Ch.P., Mpenda, Z.T., Sieber, S. (2020). The Determinants of Farmers' Choice of Markets for Staple Food Commodities in Dodoma and Morogoro, Tanzania. Agriculture, vol. 10(142). DOI:10.3390/agriculture10050142.

22. Kedaitiene, A., Hockmann, H. (2002). Milk and Milk Processing Industry in Lithuania: an Analysis of Horizontal and Vertical Integration. IAMO Discussion Papers, no. 44. https://ideas.repec.org/p/zbw/iamodp/14930.html. Accessed: 05.11.2020.

23. Key, N., Sadoulet, E., De Janvry, A. (2000). Transactions Costs and Agricultural Household Supply Response. American Journal of Agricultural Economics, vol. 88(2), pp. 245-259.

24. MacDonald, J., Perry, J., Ahearn, M., Banker, D., Chambers, W., Dimitri, C., Key, N., Nelson, K., Southard, L. (2004). Contracts, Markets, and Prices: Organizing the Production and Use of Agricultural Commodities. SSRN Electronic Journal, vol. 837. DOI: 10.2139/ssrn.753567.

25. Martey, E., Al-Hassan, R.M., Kowornu, J.K. (2012). Commercialization of Smallholder Agriculture in Ghana; A Tobit Regression Analysis. African Journal of Agricultural Research, vol. 7(14), pp. 2131-2141.

26. North, D.C. (1990). Institution, Institutional Change and Economic Performance. Cambridge: Cambridge University Press, p. 3.

27. Oparinde, L., Daramola, A. (2014). Determinants of Market Participation by Maize Farmers in Ondo State, Nigeria. Journal of Economics and Sustainable Development, vol. 5, pp. 69-77.

28. Pazaj, E., Dumi, A. (2015). Economic Coordination Contracts and their Role in Integration of Farmers Markets. Academic Journal of Interdisciplinary Studies, vol. 4(1), pp. 435-444. DOI: 10.5901/mjss.2015.v4n1p435.

29. Pendleton, L., Howe, L. (2002). Market Integration, Development, and Smallholder Forest Clearance. Land Economics, vol. 78(1), pp. 1-19. DOI:10.2307/3146919.

30. Piketty, T. (2013). Capital in the Twenty-First Century. Éditions du Seuil. Cambridge: Harvard University Press, pp. 65, 71 and 204. 
31. Poczta-Wajda, A. (2016). Interest Groups and Rent Seeking in Agriculture - a Theoretical Approach. In: Political Rents of European Farmers in the Sustainable Development Paradigm. International. National and regional perspective (ed. B. Czyżewski). Warsaw: PWN, pp. 48-58.

32. Rucabado-Palomar, T., Cuellar-Padilla, M. (2020). Short Food Supply Chains for Local Food: a Aifficult Path. Renewable Agriculture and Food Systems, vol. 35, pp. 182-191.

33. Stanef, M.R. (2012). Increasing Labor Market Participation and Reducing Structural Unemployment in Rural and Urban Areas of Europe. Case Study - Romania. Theoretical and Applied Economics, vol. XIX, no. 3(568), pp. 149-156.

34. Statistics Poland (2020). Household Budget Survey in 2019. Warsaw: Statistics Poland Press Office.

35. Statistics Poland (2020). Statistical Yearbook of Agriculture 2019. Warsaw: Statistics Poland Press Office.

36. Turkalj, D., Biloš, A., Kelić, I. (2015). Integration of Croatian Farmers in the EU Information Society - Issues and Implications. Ekonomski Vjesnik, vol. 28, pp. 41-52.

37. White, J., Gorton, M. (2011). A Comparative Study of Agrifood Chains in Moldova, Armenia, Georgia,Russia, and Ukraine. In: The Dynamics of Vertical Coordination in Agrifood Chains in Eastern Europe and Central Asia (ed. J.F.M. Swinnen). Washington: World Bank. 